\title{
Molecular Analysis and Chromosome Mapping of Repetitive DNAs in the Green Terror Andinoacara rivulatus (Cichlidae: Cichlasomatini)
}

\author{
Mauro Nirchio, ${ }^{1,2}$ Fabilene Gomes Paim, ${ }^{3}$ Ricardo Britzke, ${ }^{2,3}$ Anna Rita Rossi, ${ }^{4}$ \\ Valentina Milana, ${ }^{4}$ and Claudio Oliveira ${ }^{3}$
}

\begin{abstract}
Neotropical cichlids include hundreds of species whose taxonomy has benefited of molecular phylogeny and whose karyotype evolution has been related to the amount and distribution of different classes of repetitive sequences. This study provides the first integrative molecular (cytochrome c oxidase subunit 1 and $16 \mathrm{~S}$ sequences) and cytogenetic analyses of wild samples of the green terror Andinoacara rivulatus, a cichlid naturally distributed in Ecuador and spread throughout the world as an aquarium pet. Molecular data revealed that sequences of green terror constitute a single monophyletic clade within the genus and allowed species attribution of uncertain samples previously cytogenetically analyzed. Chromosome number $(2 n=48)$ conforms to the general trend observed within neotropical cichlids. However, mapping of different classes of repeated sequences (18S rDNA, 5S rDNA, U1 snDNA and telomeric) revealed the presence of features uncommon among representatives of these fishes, like multiple major rDNA sites, and suggested a recent occurrence of rearrangements (fusion/inversion) in two chromosome pairs.
\end{abstract}

Keywords: Cichliformes, Ecuador, heterochromatin, in situ hybridization, ITS, NORs

\section{Introduction}

T He family Cichlidae, which presently includes 1723 valid species, ${ }^{1}$ is the most species-rich nonostariophysan freshwater fish family and one of the major vertebrate group. ${ }^{2}$ Fishes of this family are widespread distributed in Africa, Latin America, and Madagascar, and are also present (with a low number of species) in South India and the Middle East. ${ }^{3}$ Neotropical cichlids belong to Cichlinae, one of the four cichlids subfamilies, whose taxonomy has long and repeatedly been revised. ${ }^{4}$ The 571 species of this subfamily ${ }^{1}$ are organized into 7 tribes. ${ }^{5}$ The tribe Cichlasomatini has $>70$ species and 11 genera, one of which, Andinoacara ${ }^{6}$ is widely distributed throughout NW South America and includes 8 valid species. ${ }^{7}$ Among these, Andinoacara rivulatus ${ }^{8}$ is one of the 38 native cichlid species present in Ecuador. ${ }^{9}$ It is commonly known as green terror, but this name is not univocal as it was originally associated with Aequidens rivulatus, now split into two species, An. rivulatus (distributed in Ecuador and northwestern Peru) and A. stalsbergi ${ }^{10}$ (present in trans-
Andean rivers and lakes at the Peruvian Pacific coast). ${ }^{11,12}$ Molecular phylogeny showed that these two sister taxa diverged $\sim 2.9$ million years ago. ${ }^{7}$ The green terror is commercialized throughout the world as an aquarium pet, sometimes crossed with Andinoacara cf. pulcher to obtain hybrids with the size and color of $A$. pulcher, and the orange seams of the An. rivulatus, both on the dorsal and caudal fin. In addition, An. rivulatus represents an important source of food and employment for populations of the northwestern Peru (Piura province) on which many fishermen and fish traders depend, ${ }^{13}$ and in Ecuador, it is one of the native wild species most consumed by the population in all the western provinces (Guayas, Manabí, Los Ríos, El Oro, Santo Domingo, and Esmeraldas). ${ }^{14}$ Although this species has not yet been assessed in the IUCN Red List, currently its capture without any control has generated problems of over exploitation with the consequent risk of affecting natural populations. ${ }^{15}$

Fish cytogenetics is a very active research area that provides information for taxonomy and for the understanding of the phylogenetic relationships among taxa. ${ }^{16-23}$ The most

\footnotetext{
${ }^{1}$ Departamento de Acuicultura, Escuela de Ciencias Aplicadas del Mar, Núcleo de Nueva Esparta, Universidad de Oriente, Porlamar, Venezuela.

${ }^{2}$ Departamento de Acuicultura, Facultad de Ciencias Agropecuarias, Universidad Técnica de Machala, Machala, Ecuador.

${ }^{3}$ Departamento de Morfologia, Instituto de Biociências Universidade Estadual Paulista, UNESP, Botucatu, Brazil.

${ }^{4}$ Dipartimento di Biologia e Biotecnologie "C. Darwin," Sapienza-Università di Roma, Rome, Italy.
} 
recent checklist of cytogenetically analyzed fish species reveals that only $\sim 8 \%$ of cichlid fishes are included. ${ }^{24}$ The diploid number in the group ranges from $2 n=32$ to $2 n=60$, but in neotropical cichlids, the modal diploid number is $2 n=48 .^{25}$ Other information on the karyotype of these species includes mapping of $45 \mathrm{~S}$ or $5 \mathrm{~S}$ rDNA or description of heterochromatin patterns. ${ }^{24-26}$ Indeed, karyotypic evolution of neotropical cichlids has been related to the amount and distribution of these classes of repetitive sequences that define different genomic organization. ${ }^{25,26}$

Data on Andinoacara spp. are scanty and mostly from aquarium source. Marescalchi ${ }^{27}$ published a report on the diploid number and the karyotype formula of aquarium trade samples of $A$. pulcher $^{28}(2 \mathrm{n}=48 ; 4 \mathrm{~m}-\mathrm{sm}+44 \mathrm{st}-\mathrm{a})$ and of green terror $(2 \mathrm{n}=48 ; 8 \mathrm{~m}-\mathrm{sm}+40 \mathrm{st}-\mathrm{a})$. At that time, the scientific name of green terror was still Ae. rivulatus, so it is not clear whether the karyotype formula reported actually refers to $A n$. rivulatus or A. stalsbergi, a doubt that needs to be unraveled. Thus, the aim of this article is to perform a molecular analysis on the green terror An. rivulatus (Cichlidae: Cichlasomatini) from its native area (Ecuador) using mitochondrial sequences of two genes (16S and cytochrome c oxidase subunit 1 [COI]) for the molecular identification of samples and for the comparison with Ae. rivulatus previously analyzed by Marescalchi. ${ }^{27}$ In addition, classical staining (Giemsa, silver nitrate, C-banding) and fluorescence in situ hybridization (FISH) mapping of different classes of repetitive sequences (18S rDNA, 5S rDNA, U1 snDNA, and telomeric repeats) were applied to deeply define the karyotype of the species.

\section{Materials and Methods}

\section{Specimens collection and identification}

Fifteen specimens of An. rivulatus (three males, six females, and six unsexed) were collected with a seine net in several locations of El Oro and Guayas Provinces Ecuador (Fig. 1) (Supplementary Table S1). Identification of samples was performed following morphological criteria. ${ }^{29}$ Fish were transported to the laboratory in sealed plastic bags ( 32 inches) containing 2 gallons of water and replacing the air with pure oxygen, and finally kept in an aquarium until their utilization for cytogenetic preparations (see the Cytogenetic analysis section of Materials and Mehtods). The experiments followed ethical conducts, in accordance with Institutional Authorization Research Project 396/2016, Universidad Técnica de Machala (UTMACH), and approved by the Bioscience Institute/Universidade Estadual Paulista (UNESP) Ethics Committee on use of animals (Protocol No. 1058/2017) through the cooperation agreement signed on March 18, 2015. A piece of muscle was collected from each specimen and preserved in $95 \%$ ethanol for molecular analysis. Voucher specimens fixed in $10 \%$ formalin are deposited in the Ichthyology Collection of the Laboratório de Biologia e Genética de Peixes of UNESP and in the UTMACH (Supplementary Table S1).

\section{Molecular analysis}

Total DNA was extracted from ethanol-preserved muscle samples using the Wizard Genomic DNA Purification Kit (Promega, Madison, WI). Partial sequences of mitochondrial genes COI and 16S rRNA were amplified using polymerase chain reaction (PCR) with the following primers: Fish F1 and
Fish R1 for the COI gene, ${ }^{30}$ and 16 Sar and 16 Sbr for the $16 \mathrm{~S}$ rRNA gene. ${ }^{31}$ PCRs were carried out in an Applied Biosystems thermocycler (Applied Biosystems, Foster City, CA) following protocols reported by Milana et al. ${ }^{32}$ The BigDye sequencing kit cycle terminators (Applied Biosystems) were used as reagent component in all sequencing reactions, according to the manufacturer's instructions, and sequences were analyzed using ABI PRISM 3130 Genetic Analyzer (Applied Biosystems).

Sequences were aligned using the software Clustal $X .^{33}$ The basic local alignment search tool (BLAST, https://blast .ncbi.nlm.nih.gov/Blast) was used to search on GenBank database for similar sequences to confirm species assignment. Sequence of Andinoacara spp. available in GenBank database was retrieved and included in analysis (Supplementary Table S1); Acaronia nassa ${ }^{34}$ was used as out-group.

Phylogenetic reconstruction was obtained from the data set with neighbor joining (NJ), maximum likelihood (ML) and Bayesian inference (BI) analyses. NJ and ML analyses (1000 bootstrap replicates) were performed using MEGA $5^{35}$ and PhyML 3.0, ${ }^{36}$ respectively. Bayesian analyses were carried out as implemented in MrBayes 3.1.2. ${ }^{37}$ Two independent runs of four Markov chains, each for 1,000,000 generations, were performed. ModelTest 3.7 38 and MrModelTest 2.3 39 were used to select the evolutionary models that best fit the data set for the ML and the BI analyses, respectively. The Akaike information criterion was used.

\section{Cytogenetic analysis}

Fish were injected intramuscularly with a yeast-glucose solution for mitosis stimulation ${ }^{40}$; after $24 \mathrm{~h}$, each fish received an intra-abdominal injection of $0.0125 \%$ colchicine $(1.0 \mathrm{~mL} / 100 \mathrm{~g}$ of body weight) $50 \mathrm{~min}$ before being sacrificed by a numbing overdose of benzocaine $(250 \mathrm{mg} / \mathrm{L})$ as recommended by the American Veterinary Medical Association. ${ }^{41}$ Mitotic chromosomes were obtained following the conventional airdrying method from kidney cell suspension. ${ }^{42}$

For the conventional karyotype, slides were stained for 20 min with $10 \%$ Giemsa in phosphate buffer at $\mathrm{pH} 6.8$. Active nucleolus organizer regions (NORs) were revealed by silver (Ag) staining. ${ }^{43}$ For C-banding, metaphase plates were exposed to depurination of chromatin with $\mathrm{HCl}$, denaturation of the DNA with $\mathrm{BaOH}$, and removal of the chains of denatured DNA in hot saline sodium citrate $2 X$ concentrate. ${ }^{44}$

The 5S rDNA and 18S rDNA (ribosomal genes), U1 snRNA gene clusters (U1 snRNA is a noncoding RNA that forms part of the spliceosome), ${ }^{45}$ and telomeric repeats were mapped onto chromosomes by FISH. ${ }^{46}$ Probes were obtained and labeled by PCR from the genome of Hypsolebias flagellatus ${ }^{47}$ using the primers 5SA (5'-TCA ACC AAC CAC AAA GAC ATT GGC AC- $\left.3^{\prime}\right)$ and 5SB (5'-TAG ACT TCT GGG TGG CCA AAG GAA TCA-3') for $5 \mathrm{~S}$ rDNA, ${ }^{48} 18 \mathrm{~S} 6 \mathrm{~F}\left(5^{\prime}\right.$-CTC TTT CGA GGC CCT GTA AT-3') and 18S6R (5'-CAG CTT TGC AAC CAT ACT CC-3') for $18 \mathrm{~S}$ rDNA, ${ }^{49}$ U1F $\left(5^{\prime}\right.$-GCA GTC GAG ATT CCC ACA TT-3') and U1R (5'-CTT ACC TGG CAG GGG AGA TA-3') for U1 snDNA, ${ }^{50}$ and (TTAGGG) 5 and (CCCTAA)5 for telomeric repeats. ${ }^{51}$ The $5 \mathrm{~S}$ rDNA and telomeric probes were labeled with biotin-16-dUTP $\left(2^{\prime}\right.$ deoxyuridine $5^{\prime}$-triphosphate), and the $18 \mathrm{~S}$ rDNA and U1 snDNA probes were labeled by including digoxigenin-11dUTP in the PCR. Hybridization was detected with fluorescein- 


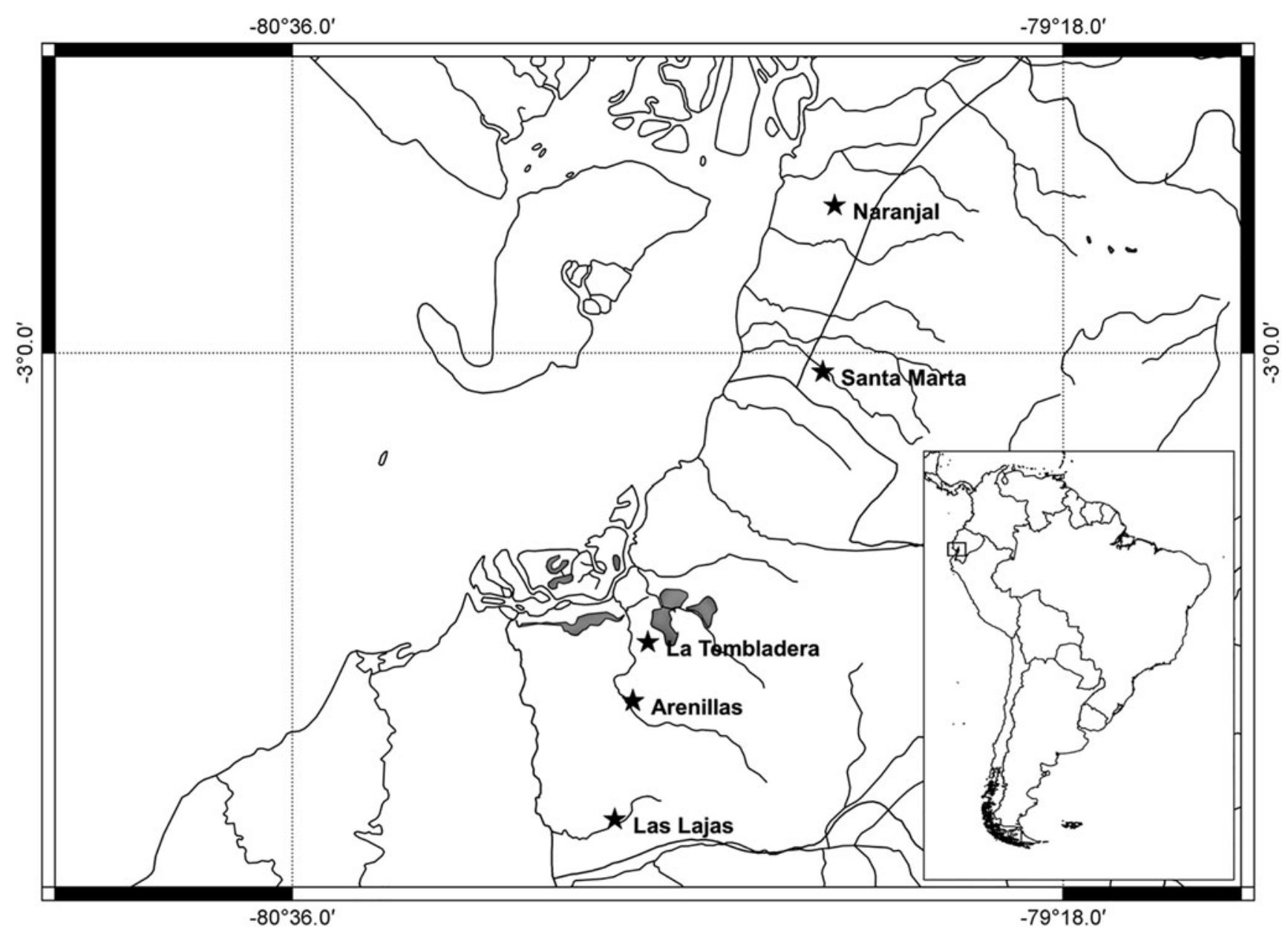

FIG. 1. Sampling area of Andinoacara rivulatus: stars indicate the different sampling sites.

conjugated avidin (Sigma-Aldrich, www.sigma-aldrich.com) and antidigoxigenin-rhodamine conjugate (Roche Diagnostics, www.roche.com), respectively. Chromosomes were counterstained with 4,6-diamidino-2-phenylindole included in the Vectashield mounting medium (Vector Laboratories, Ltd., Peterborough, UK).

The chromosome spreads were analyzed under an Olympus BX61 epifluorescence microscope (Olympus, www.olympus .com) and images were captured with an Olympus DP70 digital camera using Image-Pro plus 6.0 software (Media Cybernetics). Images were merged and edited for optimization of brightness and contrast using Photoshop CS5 program (Adobe Systems, www.adobe.com). Chromosomes were arranged in decreasing order and classified as metacentric (m), submetacentric (sm), and subtelocentric/acrocentric (st/a). For calculating the number of chromosome arms (fundamental number, FN), the st/a chromosomes were considered as uniarmed and $\mathrm{m}$-sm elements as biarmed.

\section{Results}

\section{Molecular analysis}

Sequences obtained in this study for COI (651 base pairs) and $16 \mathrm{~S}$ rRNA (542 base pairs) were deposited in GenBank under accession numbers provided in Supplementary Table S1. When $16 \mathrm{~S}$ rDNA sequences obtained in this study were
BLASTed in GenBank, they showed $99.8 \%$ similarity with those provided by Marescalchi. ${ }^{27}$ In addition, the phylogenetic reconstructions based on 16S (Supplementary Fig. S1) and COI (Fig. 2) data, which include sequences of other certainly identified Andinoacara spp. retrieved from the databases, show that An. rivulatus constitutes a single monophyletic clade. The genetic COI K2P distance between An. rivulatus and the other species of the genus ranges from $8.8 \%$ to $13 \%$ with Andinoacara biseriatus $^{52}$ and Andinoacara coeruleopunctatus, ${ }^{53}$ respectively.

\section{Cytogenetic analysis}

The analysis of 345 well-spread metaphases (20-25 per individual) of An. rivulatus showed a modal (98\%) diploid number of $2 \mathrm{n}=48$ and a karyotype composed by 2 small $\mathrm{m}$, $10 \mathrm{sm}$, and $36 \mathrm{st} / \mathrm{a}$ chromosomes (Fig. 3a) with FN of 60. Chromosomes are very similar in shape and gradually decrease in size. This makes it difficult to identify the homologues with certainty, with the exception of the unique $\mathrm{m}$ chromosome pair, identified as number 1, and of chromosome pair number 2 , which is the largest in the sm series. No morphologically differentiated chromosomes between males and females were observed. The analysis of the C-banding pattern (10 metaphases per individual) revealed constitutive heterochromatin restricted to the centromeric regions of all chromosomes (Fig. 3b). 


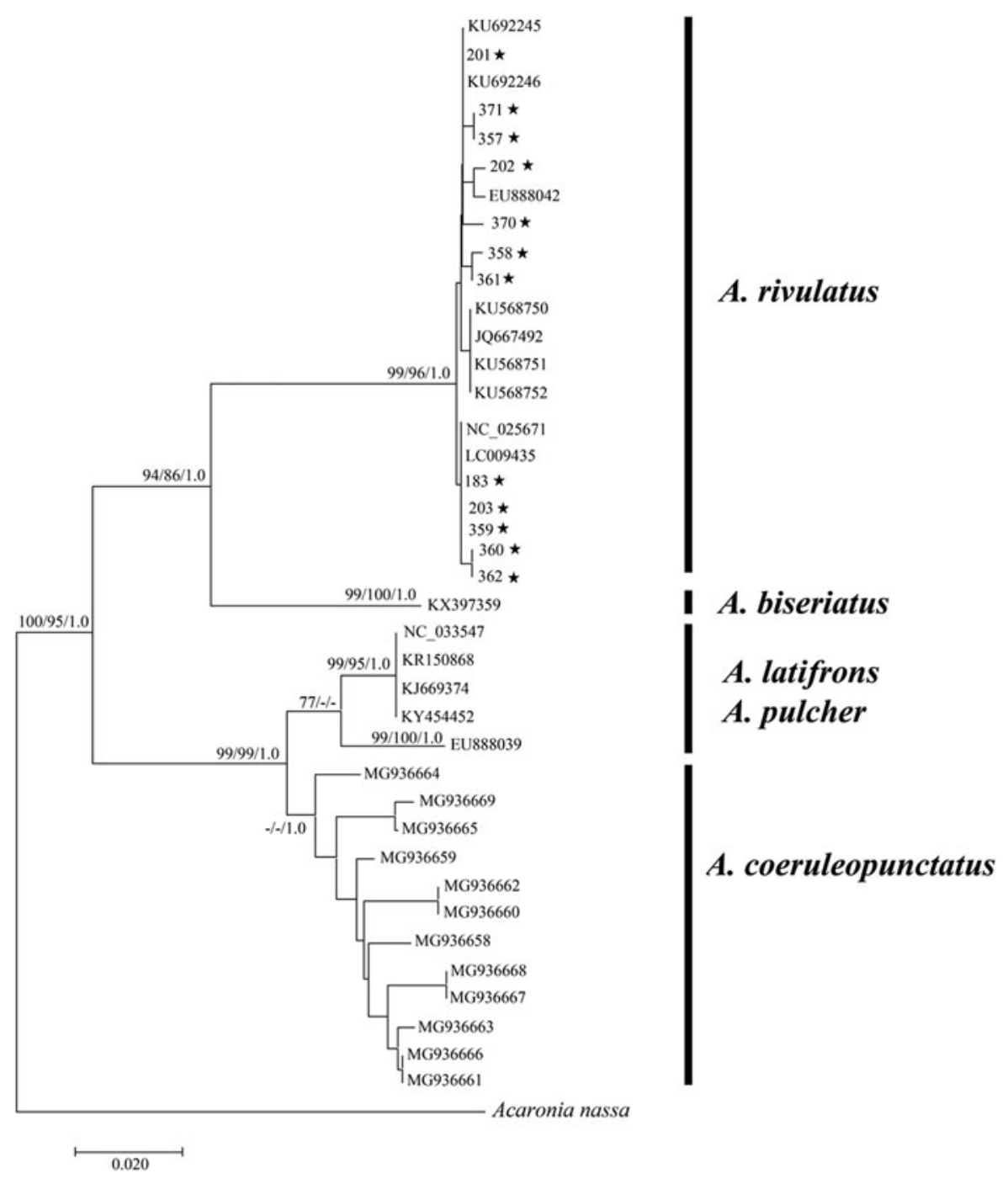

FIG. 2. NJ tree based on mitochondrial sequences of cytochrome c oxidase subunit 1 of Andinoacara. At each node, bootstrap values $>70 \% \quad(\mathrm{NJ}$ and maximum likelihood) and posterior probabilities $>0.9$ (Bayesian inference) are shown. Specimens sequenced in this study and cytogenetically examined are indicated by stars. $\mathrm{NJ}$, neighbor joining.
Twenty silver nitrate-stained metaphases were photographed from each individual, and two to three actively transcribing NORs, localized on the short arms of an sm chromosome pair and in pericentromeric position of an st/a chromosome pair, were identified (Fig. $4 \mathrm{a}-\mathrm{c}$ ). Most of the metaphases show only two chromosomes positively silver stained, either in homozygous or heterozygous combination, although some metaphases showing three or four Ag-NORbearing chromosomes were observed (Fig. 4d, e). A maximum of four silver-stained nucleoli were observed also in interphasic cells (Fig. 4f).

Double FISH experiments using rDNA probes (Fig. 5) confirmed the presence of two pairs of $18 \mathrm{~S}$ rDNA positive sites and a single pair of 5S rDNA sites. The analysis of $\sim 15$ metaphases per individual showed the major ribosomal genes localized consistently on the short arms of a medium sized sm chromosome pair (pair 5) and on the pericentromeric position of an st/a chromosome pair (pair 19) (Fig. 5a); in a single individual (collected at Arenillas), two additional and small $18 \mathrm{~S}$ rDNA positive sites were observed on a pair of st/a chromosomes (Fig. 5b). The minor ribosomal genes are localized terminally on the tip of the unique $\mathrm{m}$ chromosome pair (pair 1) (Fig. 5a). U1 snDNA is localized on the tip of the short arms of a medium-sized sm pair, likely chromosome pair 3 (Fig. 5c).

In situ hybridization with the telomeric probe (five welldefined metaphases per individual) provided positive signals at the ends of all chromosomes and interstitial positive sites (ITSs) on two chromosome pairs: in the pericentromeric region on the unique $\mathrm{m}$ chromosome pair (pair 1) and on an sm chromosome pair (pair 2) (Fig. 6).

\section{Discussion}

Molecular data demonstrated that specimens examined in this survey belong to the same species examined by Marescalchi $^{27}$ and actually correspond to An. rivulatus. This species is unambiguously defined within the genus as a monophyletic group, according to the previous phylogenetic data by Musilová et $a .^{7}$ where it represented one of the four Andinoacara taxa belonging to the southern clade.

Cytogenetic data provided here show that An. rivulatus has a chromosomal complement of $2 \mathrm{n}=48(12 \mathrm{~m}$-sm $+36 \mathrm{st}-\mathrm{a}$, $\mathrm{FN}=60$ ), which differs in the karyotype formula reported by Marescalchi ${ }^{27}(2 \mathrm{n}=48 ; 8 \mathrm{~m}-\mathrm{sm}+40 \mathrm{st}-\mathrm{a})$. However, these differences could be due to a different degree of condensation 
FIG. 3. Conventional Giemsa-stained (a) and C-banded (b) karyotype of Andinoacara rivulatus. $\mathrm{m}$, metacentric; sm, submetacentric; st/a, subtelocentric/acrocentric.

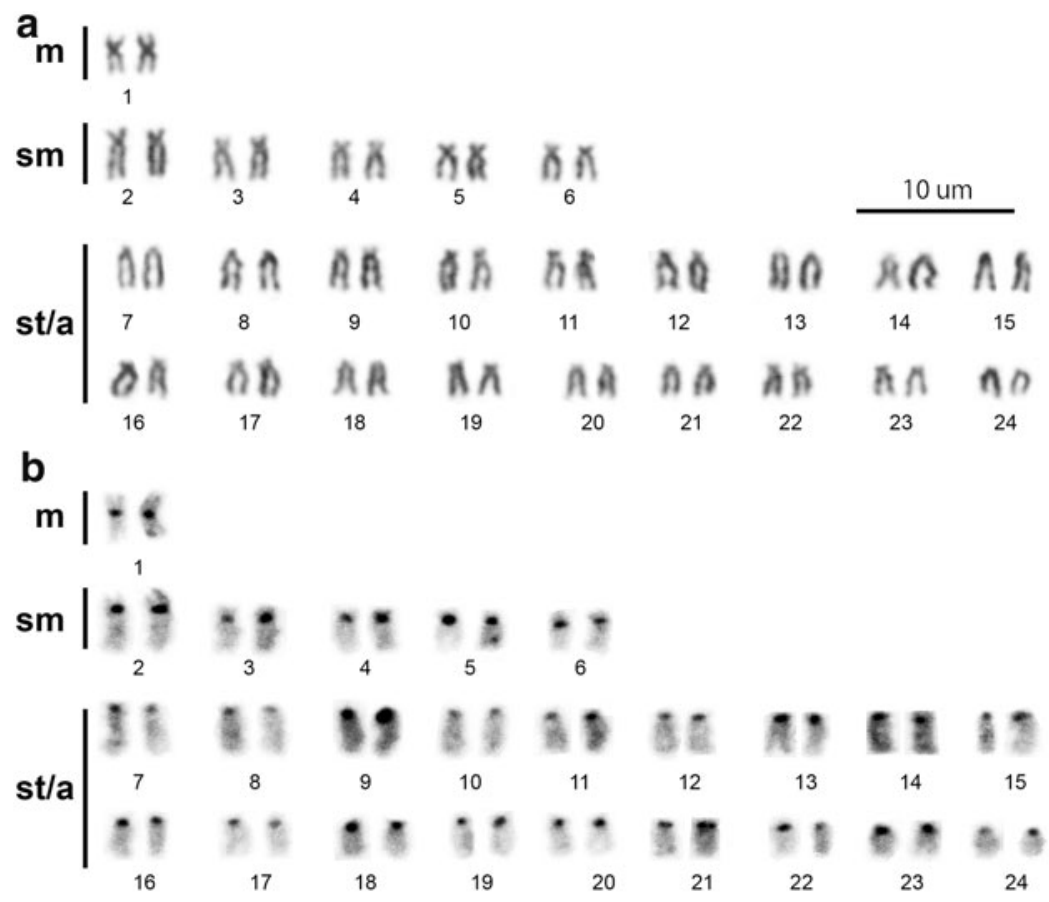

of chromosomes that make their classification and comparison difficult. A diploid number $2 \mathrm{n}=48$ is the most common in fishes, ${ }^{51,54}$ and it is also the one typically observed in neotropical cichlids. ${ }^{55-58}$ However, many species of this group, despite sharing this chromosome number, differ in the karyotype formula, an evidence that could be explained by intrachromosomal rearrangements like centromeric shifts. As a result of these processes, karyotypic diversity in neotropical cichlids has a higher rate of evolution than that observed in cichlids from Old World. ${ }^{25}$ Among the 25 species of the tribe
Cichlasomatini (Supplementary Table S2), the same chromosome number is associated with many different number of chromosome arms and it is not possible to identify a general trend; however, some of the genera (Laetacara, ${ }^{59}$ Nanna$\operatorname{cara}^{60}$ ) seem to be more prone to chromosome number reduction than others. Within the genus Andinoacara, the only other species cytogenetically examined to date, A. pulcher, share the same chromosome number of An. rivulatus. Although $A$. pulcher is characterized by the presence of a large $\mathrm{m}$ chromosome pair, it is much larger than the others of the
FIG. 4. Metaphases of $A n$ dinoacara rivulatus stained with $\mathrm{AgNO}_{3}$ showing (a-c) two (d) three, and (e) four positive sites (arrows). Enlargements and schematic representation of the silverstained NOR-bearing chromosomes are shown. (f) Interphasic nuclei showing one to four silver-stained nucleoli.
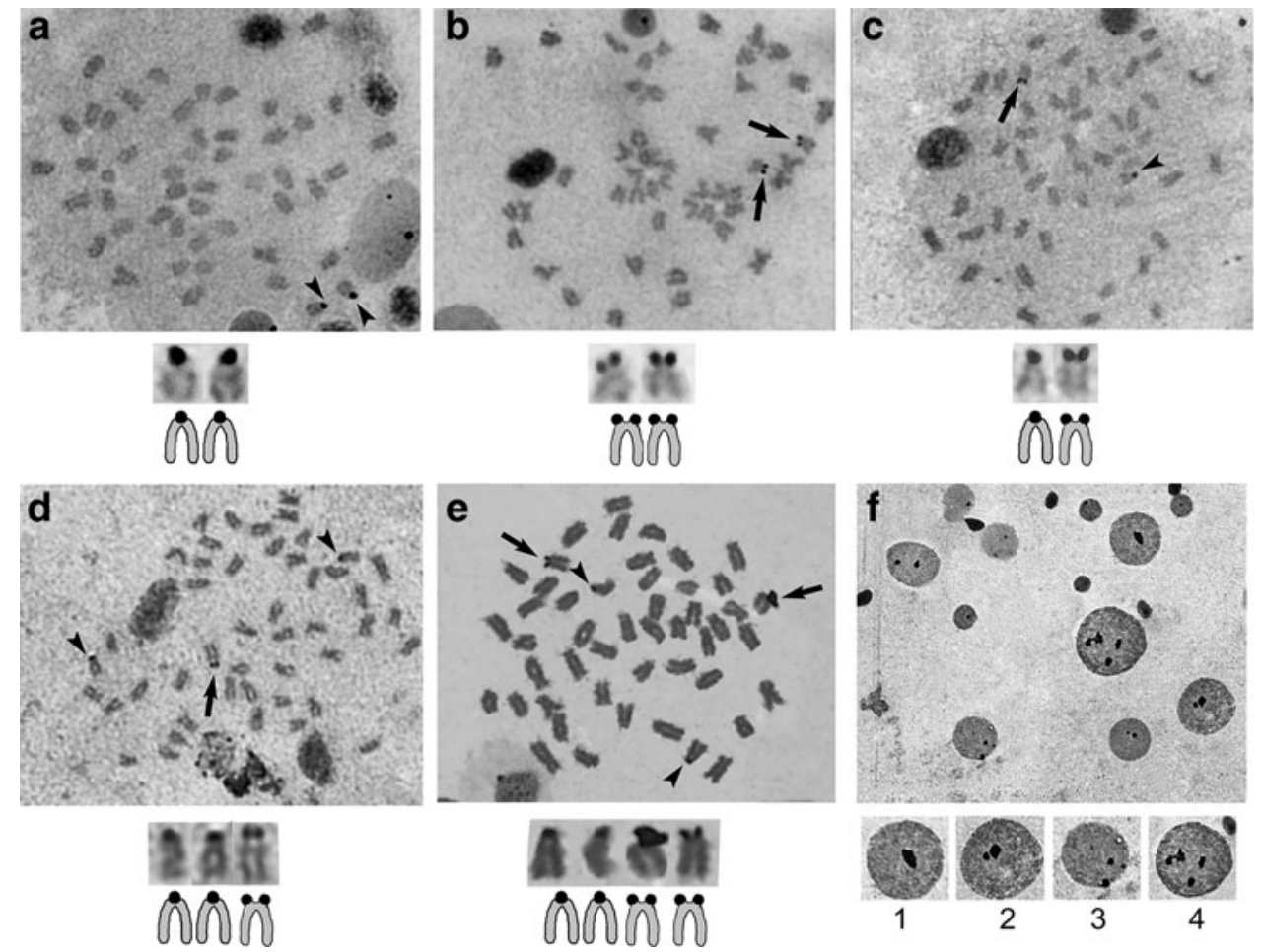

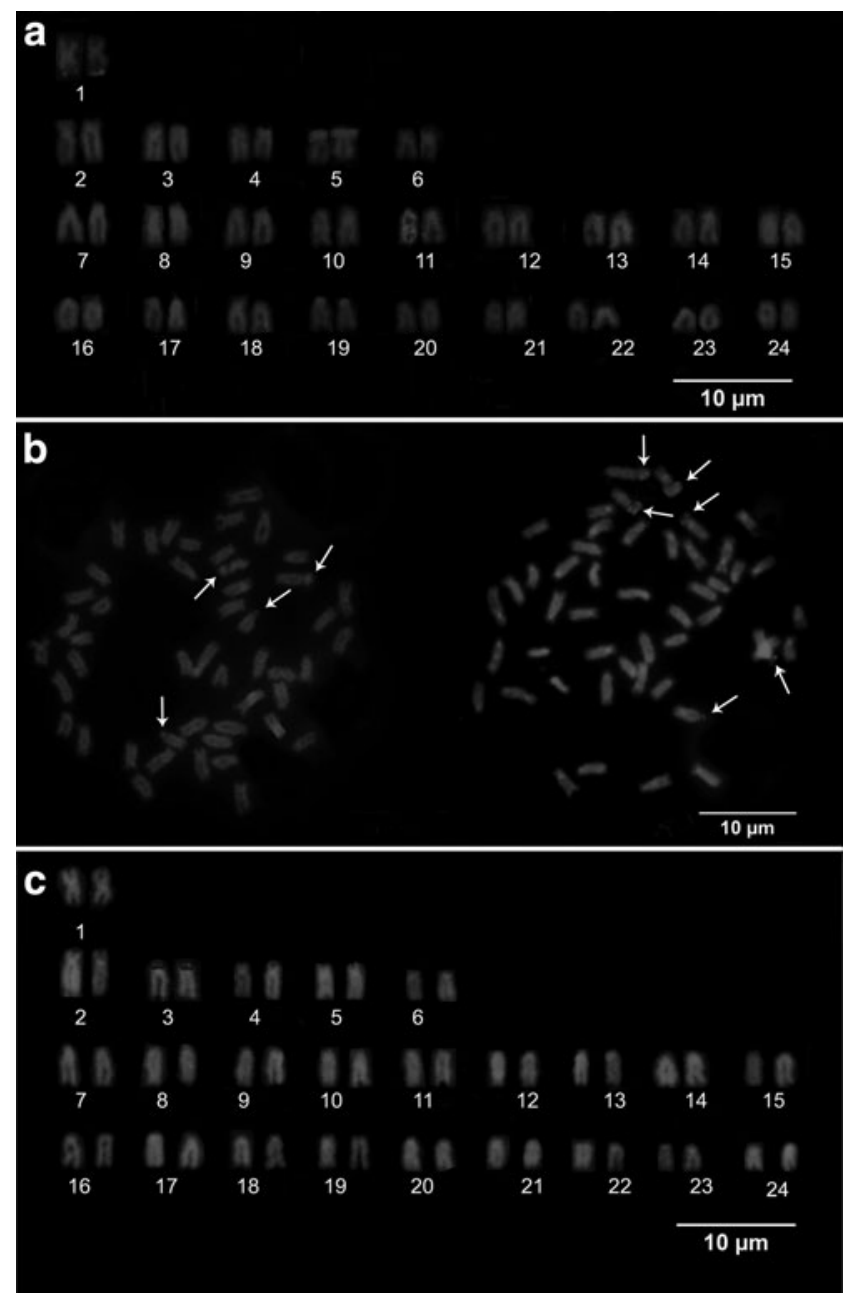

FIG. 5. FISH/DAPI. (a) Karyotypes of Andinoacara rivulatus under double FISH with 5S rDNA (positive signals on pair 1) and 18S rDNA (positive signals on pairs 5 and 19) probes. (b) metaphase plates showing four (left) and six (right) 18S rDNA sites (arrows). (c) Karyotypes of An. rivulatus under single FISH with U1 snDNA probe. FISH, fluorescence in situ hybridization; DAPI, 4,6-diamidino-2-phenylindole.

complement, and it is not comparable with any chromosome of An. rivulatus. The analysis of other species of the genus will be necessary to clarify whether and how much this large $\mathrm{m}$ chromosome pair is spread among species of Andinoacara and whether there is any relationship between large and small $\mathrm{m}$ chromosomes.

The presence of ITS in two chromosome pairs of An. rivulatus, reported also in representatives of different orders of fishes $^{61}$ including those of the subfamily Cichlinae within Cichliformes, ${ }^{62}$ suggests a recent occurrence of chromosome rearrangement (fusions and inversions) during the karyotype diversification in cichlids. Indeed, telomeric repeats when present in sites other than those at the ends of the chromosomes, tend to shorten, to be lost over time, or to become inactive, ${ }^{61,63,64}$ and the detection of residual sequences could be difficult ${ }^{65}$; as a consequence, ITS could be considered not only a marker of chromosome rearrangements but also of their time of occurrence.

The heterochromatin distribution pattern in the centromeric or pericentromeric chromosome regions is common to

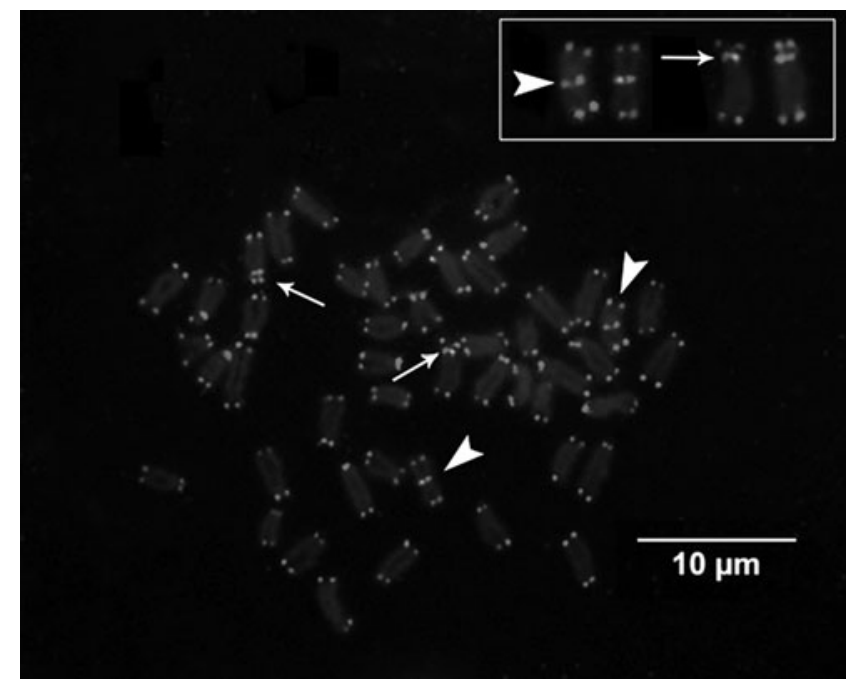

FIG. 6. Metaphase of Andinoacara rivulatus assayed by FISH using telomeric probes and counterstained by DAPI. Interstitial positive sites on chromosome pair $1(\mathrm{~m})$ and pair 2 (sm) are indicated by arrows and arrowheads, respectively.

the other neotropical cichlids ${ }^{25,62}$ and thus it seems to be not informative. This pattern suggests the absence of sex chromosomes, as in fish these chromosomes tend to accumulate repeated sequences partly or completely heterochromatic, ${ }^{66-68}$ which could be detected as heterochromatic blocks. ${ }^{69}$

Location of ribosomal genes has been investigated in thousands of species, making these chromosomal regions a preferred marker in comparative cytogenetics and systematic studies. $^{70}$ An. rivulatus FISH assays with $18 \mathrm{~S}$ rDNA probe demonstrated that the polymorphism observed after silver staining was due to a different activity of NORs that was already reported in many animals ${ }^{68}$ including fishes ${ }^{72}$ and Cichlidae. ${ }^{73}$ Usually the mechanisms of inactivation of NORs include elimination of rDNA, DNA methylation, and gene silencing due to position effects induced by heterochromatin (C-bands) and/or telomeres and transposable elements. ${ }^{71,74,75}$ It has also been shown that different rDNA units could be present in the genome and they are not randomly expressed. ${ }^{76}$ The presence of two additional sites in one individual requires a more detailed analysis, on a wider number of individuals, to assess whether an interpopulation variation in constitutive ribosomal genes exists or, on the contrary, it is an isolated case and/or it might be linked to the difficulty in detecting inactive major rDNA sites with a low copy number of genes. ${ }^{77}$ Indeed, the copy number of genes at these sites can change easily ${ }^{78}$ as an adaptive response to genome stress. $^{79}$

As far as the presence of multiple rDNA sites is concerned, this condition is not very commonly detected in fishes. Indeed, in this group of vertebrates, the presence of a single NOR-bearing chromosome pair is considered as the plesiomorphic condition. ${ }^{80}$ It characterizes ancient nonteleost actinopterygian fishes, ${ }^{81}$ most primitive actinopterygians not originated by polyploidization, and is the most common conditions in teleost species, being shared by $72 \%$ of the taxa. ${ }^{82}$ Cichlids generally conform to this picture: the animal rDNA database (www.animalrdnadatabase.com) reports 39 records for $45 \mathrm{~s}$ rDNA in this family and a single site of these rDNA clusters is the general trend, according to the 
observation of a single pair of Ag-NORs. ${ }^{24,25}$ This was described as the probable symplesiomorphic condition in the group. ${ }^{56}$ Few exceptions have been reported in Cichlasoma sanctifranciscense ${ }^{83,84}$ Geophagus brasiliensis, ${ }^{82,85}$ Uaru amphiacanthoides, ${ }^{34}$ and Pterophyllum leopoldi, ${ }^{6,86}$ and An. rivulatus (this study): they would represent a derived character in neotropical cichlids.

An. rivulatus minor ribosomal genes are localized on a single chromosome pair, with no synteny with major ribosomal genes. This pattern corresponds to what is generally observed in fishes, ${ }^{87,88}$ including Cichlidae, ${ }^{84,89}$ being shared by 26 out of the 38 analyzed species of the family (www .animalrdnadatabase.com), with few exceptions. ${ }^{62}$ Indeed, these genes usually show high variability at molecular level, as they are associated with other genes, microsatellites or transposable elements, and low variability at chromosomal level. ${ }^{88}$

Regarding U1 snRNA, chromosomal localization of coding genes has been investigated so far only in a few teleost fishes of the family Hepsetidae, ${ }^{16}$ Mugilidae, ${ }^{20}$ Merlucciidae, ${ }^{90}$ and Characidae, ${ }^{50}$ and in the latter they are often associated with $5 \mathrm{~S}$ ribosomal genes. In Cichlidae, ${ }^{91}$ mapping of the U1 snRNA in 19 species belonging to different subfamilies had shown positive signals located on a single chromosome pair, mainly (14 out of 19 species) terminally on the long arms. This is also the case of the unique species belonging to the Cichlasomatini tribe Aequidens tetramerus. ${ }^{34}$ Thus the terminal location on short chromosomal arms detected in An. rivulatus could be a derived condition, from chromosome rearrangements.

We provide here new data on the cytogenetic profile of $A n$. rivulatus, the first on wild samples and thus the reference for the species, with mapping of different gene families, and the molecular identification of specimens. The molecular phylogeny provides clear relationships within Andinoacara; further in-depth cytogenetic studies on congeneric species are required to better understand the karyotype evolutionary history of this group within neotropical cichlids.

\section{Acknowledgment}

The authors thank an anonymous reviewer for comments and suggestions on the article.

\section{Disclosure Statement}

No competing financial interests exist.

\section{Funding Information}

This study was financially supported by Centro de Investigaciones of Universidad Técnica de Machala (grant no. PR-022-006) to M.N., by Sapienza Università di Roma (grant no. RP11816430E2E16A) to A.R.R. and by FAPESP (grant no. 2014/26058-3) to C.O.

\section{Supplementary Material}

Supplementary Figure S1

Supplementary Table S1

Supplementary Table S2

\section{References}

1. Fricke R, Eschmeyer WN, Fong JD. Species by family/ subfamily. Catalog of fishes: Genera, species, references.
2019. Available at http://researcharchive.calacademy.org/ research/ichthyology/catalog/speciesbyfamily.asp. Accessed April 16, 2019.

2. Nelson JS, Grande TC, Wilson MVH. Fishes of the World. Fifth edition. John Wiley \& Sons, 2016. Hoboken, New Jersey.

3. Genner MJ, Seehausen O, Lunt DH, Joyce DA, Shaw PW, Carvalho GR, et al. Age of cichlids: new dates for ancient lake fish radiations. Mol Biol Evol 2007;24:1269-1282.

4. Kullander SO. Family cichlidae. In: Checklist of the Freshwater Fishes of South and Central America. Reis RE, Kullander SO, and Ferraris CJ Jr (eds), pp. 605-654, Edipucrs, Porto Alegre, 2003.

5. López-Fernández H, Winemiller KO, Honeycutt RL. Multilocus phylogeny and rapid radiations in Neotropical cichlid fishes (Perciformes: Cichlidae: Cichlinae). Mol Phylogenet Evol 2010;55:1070-1086.

6. Musilová Z, Říčan O, Novák J. Phylogeny of the Neotropical cichlid fish tribe Cichlasomatini (Teleostei: Cichlidae) based on morphological and molecular data, with the description of a new genus. J Zoolog Syst Evol Res 2009;47:234-247.

7. Musilová Z, Říčan O, Říčanová S, Janšta P, Gahura O, Novák J. Phylogeny and historical biogeography of transAndean cichlid fishes (Teleostei: Cichlidae). Verteb Zool 2015;65:333-350.

8. Günther ACLG. Second list of cold-blooded vertebrata collected by Mr. Fraser in the Andes of western Ecuador. Proc Zool Soc Lond 1860;1860:402-420.

9. Barriga R. Notes on the taxonomy of Andinoacara species. 2012. Available at http://bibdigital.epn.edu.ec/handle/ 15000/5068. Accessed April 10, 2019.

10. Musilová Z, Schindler I, Staeck W. Description of Andinoacara stalsbergi sp. n. (Teleostei: Cichlidae: Cichlasomatini) from Pacific coastal rivers in Peru, and annotations on the phylogeny of the genus. Vertebr Zool 2009;59:131-141.

11. Musilová Z, Schindler I, Staeck W. Phylogeny of the Neotropical cichlid fish tribe Cichlasomatini (Teleostei: Cichlidae) based on morphological and molecular data, with the description of a new genus. J Zool Syst Evol Res 2009;47:234-247.

12. Schindler I, Morgenstern R. Anmerkungen zur Taxonomie der Andinoacara-Arten [Notes on the taxonomy of Andinoacara species]. DCG Inform 2010;41:114-124.

13. Rodríguez RM. Bioecological aspects of Aequidens rivulatus (Pisces: Cichlidae) of the Villa Maria wetland, Chimbote (Perù), for future breeding. In: Technical Communication CIVA. pp. 101-107, 2004.

14. González Vélez MA. Meristic and morphometrics features of native freshwater fishes of Ecuador. 2017. Available at http://helvia.uco.es/bitstream/handle/10396/15214/ 2017000001642.pdf?sequence $=1$

15. Jiménez-Prado P, Aguirre W, Laaz-Moncayo E, NavarreteAmaya R, Nugra-Salazar F, Rebolledo-Monsalve E, et al. Guide to freswater fishes of the western slope of Ecuador. Pontifical Catholic University of Ecuador, Esmeralda (PUCESE), University of Azuay (UDA) and Museum of Natural Science of Ecuador (MECN) of the National Institute of Biodevisity, 2015.

16. Carvalho PC, de Oliveira EA, Bertollo LAC, Yano CF, Oliveira C, Decru E, et al. First chromosomal analysis in Hepsetidae (Actinopterygii, Characiformes): insights into relationship between African and Neotropical Fish Groups. Front Genet 2017;8:203. 
17. Ferreira M, Garcia C, Matoso DA, de Jesus IS, Cioffi M de $\mathrm{B}$, Bertollo LAC, et al. The Bunocephalus coracoideus species complex (Siluriformes, Aspredinidae). signs of a speciation process through chromosomal, genetic and ecological diversity. Front Genet 2017;8:120.

18. Nakayama CM, Feldberg E, Bertollo LAC. Mapping of ribosomal genes and chromosomal markers in three species of the genus Serrasalmus (Characidae, Serrasalminae) from the Amazon basin. Genet Mol Biol 2008;31:868-873.

19. Nakayama C, Jégu M, Porto JIR, Feldberg E. Karyological Evidence for a Cryptic species of piranha within Serrasalmus rhombeus (Characidae, Serrasalminae) in the Amazon. Copeia 2001;3:866-869.

20. Nirchio M, Paim FG, Milana V, Rossi AR, Oliveira C. Identification of a new mullet species complex based on an integrative molecular and cytogenetic investigation of Mugil hospes (Mugilidae: Mugiliformes). Front Genet 2018;9:17.

21. Nirchio M, Fenocchio AS, Swarça AC, Pérez JE, Granado A, Estrada A, et al. Cytogenetic characterization of hybrids offspring between Colossoma macropomum (Cuvier, 1818) and Piaractus brachypomus (Cuvier, 1817) from Caicara del Orinoco, Venezuela. Caryologia 2003;56:405-411.

22. Nirchio M, Oliveira C, Siccha-Ramirez ZR, de Sene VF, Sola L, Milana V, et al. The Mugil curema species complex (Pisces, Mugilidae): a new karyotype for the Pacific white mullet mitochondrial lineage. Comp Cytogenet 2017;11: 225-237.

23. Nirchio M, Oliveira C, Siccha-Ramirez ZR, Sene VF, Sánchez-Romero OR, Ehemann NR, et al. Cryptic Caribbean species of Scorpaena (Actinopterygii: Scorpaeniformes) suggested by cytogenetic and molecular data. J Fish Biol 2016;89:1947-1957.

24. Arai R. Fish Karyotypes: A Check List. Springer Science \& Business Media, 2011.

25. Feldberg E, Porto JIR, Bertollo LAC. Chromosomal changes and adaptation of cichlid fishes during evolution. Fish Adapt 2003;285:308.

26. Poletto AB, Ferreira IA, Cabral-de-Mello DC, Nakajima RT, Mazzuchelli J, Ribeiro HB, et al. Chromosome differentiation patterns during cichlid fish evolution. BMC Genetics 2010;11:1-12.

27. Marescalchi O. Karyotype and mitochondrial 16S gene characterizations in seven South American Cichlasomatini species (Perciformes, Cichlidae). J Zoological System 2005; 43:22-28.

28. Gill TN. Synopsis of the Fresh Water Fishes of the Western Portion of the Island of Trinidad, W. I. Ann Lyceum Nat His New York 1859;6:363-430.

29. Nicklas W, Kullander SO, Ramiro B. Andinoacara blombergi, a new species from the río Esmeraldas basin in Ecuador and a review of $A$. rivulatus (Teleostei: Cichlidae). Ichthyol Explor Fresh 2012;23:117-137.

30. Ward RD, Zemlak TS, Innes BH, Last PR, Hebert PDN. DNA barcoding Australia's fish species. Philos Trans R Soc Lond B Biol Sci 2005;360:1847-1857.

31. Palumbi SR. Nucleic acids II: the polymerase chain reaction. In: Molecular Systematics. Hillis DM, Moritz C, and Mable BK (eds), pp. 205-247, Sinauer, Sunderland, MA, 1996.

32. Milana V, Fusari A, Rossi A, Sola L. Molecular and morphological identification of an uncommon centrolophid fish. Central Europ J Biol 2011;6:440-445.
33. Thompson J. The CLUSTAL_X windows interface: flexible strategies for multiple sequence alignment aided by quality analysis tools. Nucleic Acids Res 1997;25:4876-4882.

34. Heckel J. Johann Natterer's neue Flussfische Brasilien's: nach den beobachtungen und mittheilungen des entdeckers. Ann Wiener Mus Naturgeschichte 1840;2:325-471.

35. Kumar S, Stecher G, Tamura K. MEGA7: molecular evolutionary genetics analysis version 7.0 for bigger datasets. Mol Biol Evol 2016;33:1870-1874.

36. Guindon S, Dufayard J-F, Lefort V, Anisimova M, Hordijk W, Gascuel O. New algorithms and methods to estimate maximum-likelihood phylogenies: assessing the performance of PhyML 3.0. Syst Biol 2010;59:307-321.

37. Huelsenbeck JP, Ronquist F. MRBAYES: Bayesian inference of phylogenetic trees. Bioinformatics 2001;17:754755.

38. Posada D, Crandall KA. MODELTEST: testing the model of DNA substitution. Bioinformatics 1998;14:817-818.

39. Nylander JAA, Zoology S, Posada D. MrModeltest 2.3. Program distributed by the author. Evolutionary Biology Centre, Uppsala University, 2008.

40. Lozano R, Ruiz Rejon C, Ruiz Rejon M. A method for increasing the number of mitoses available for cytogenetic analysis in rainbow trout. Stain Technol 1988;63:335338.

41. Leary SL, Underwood W, Anthony R, Gwaltney-Brant S, Poison A, Meyer R. AVMA Guidelines for the Euthanasia of Animals: 2013 Edition. American Veterinary Medical Association Schaumburg, IL, 2013. Available at https://www .spandidos-publications.com/var/AVMA\%20euthanasia\%20 guidelines\%202013.pdf. Accessed April 10, 2019.

42. Nirchio M, Oliveira C. Fish Cytogenetics, 216 pp. Universidad de Oriente, Cumaná, Venezuela, 2006.

43. Howell WM, Black DA. Controlled silver-staining of nucleolus organizer regions with a protective colloidal developer: a 1-step method. Experientia 1980;36:1014-1015.

44. Sumner AT. A simple technique for demonstrating centromeric heterochromatin. Exp Cell Res 1972;75:304-306.

45. Nilsen TW. The spliceosome: the most complex macromolecular machine in the cell? Bioessays 2003;25:11471149.

46. Pinkel D, Straume T, Gray JW. Cytogenetic analysis using quantitative, high-sensitivity, fluorescence hybridization. Proc Natl Acad Sci U S A 1986;83:2934-2938.

47. Costa W. The Simpsonichthys flavicaudatus species group (Cyprinodontiformes: Rivulidae: Cynolebiatinae): phylogenetic relationships, taxonomic revision and biogeography. Ichthyol Explor Freshwaters 2003;14:31-60.

48. Pendas AM, Moran P, Martinez JL, Garcia-Vazquez E. Applications of 5S rDNA in Atlantic salmon, brown trout, and in Atlantic salmon brown trout hybrid identification. Mol Ecol 1995;4:275-276.

49. Utsunomia R, Silva DMZ de A, Ruiz-Ruano FJ, ArayaJaime C, Pansonato-Alves JC, Scacchetti PC, et al. Uncovering the ancestry of B chromosomes in Moenkhausia sanctaefilomenae (Teleostei, Characidae). PLoS One 2016; 11:e0150573.

50. Silva DMZA, Utsunomia R, Pansonato-Alves JC, Oliveira C, Foresti F. Chromosomal mapping of repetitive DNA sequences in five species of Astyanax (Characiformes, Characidae) reveals independent location of $\mathrm{U} 1$ and $\mathrm{U} 2$ snRNA sites and association of U1 snRNA and 5S rDNA. Cytogenet Genome Res 2015;146:144-152. 
51. Ijdo JW, Wells RA, Baldini A, Reeders ST. Improved telomere detection using a telomere repeat probe (TTAGGG)n generated by PCR. Nucleic Acids Res 1991;19:4780.

52. Regan CT. The fishes of the San Juan river, Colombia. Annals Magaz Nat History 1913;12:462-473.

53. Kner, R. Eine Uebersicht der ichthyologischen Ausbeute des Herrn Professors Dr. Mor. Wagner in Central-Amerika. Sitzungsberichte der Königlich Bayerischen Akademie der Wissenschaften zu München 1863;2:220-230.

54. Galetti PM, Aguilar CT, Molina WF. An overview of marine fish cytogenetics. In: Marine Genetics. Solé-Cava AM, Russo CAM, and Thorpe JP (eds), pp. 55-62, Springer, Dordrecht, The Netherlands, 2000.

55. Nirchio M, Rossi AR, Foresti F, Oliveira C. Chromosome evolution in fishes: a new challenging proposal from Neotropical species. Neotrop Ichthyol 2014;12:761-770.

56. Feldberg E, Bertollo LAC. Nucleolar organizing regions in some species of Neotropical Cichlid fish (Pisces, Perciformes). Caryologia 1985;38:319-324.

57. Kornfield I. Descriptive genetics of cichlid fishes. In: Evolutionary Genetics of Fishes. Turner BJ (ed), pp. 591616. Springer, Boston, MA, 1984.

58. Thompson KW. Cytotaxonomy of 41 species of Neotropical Cichlidae. Copeia 1979;4:679-691.

59. Kullander SO. Cichlid fishes of the Amazon River drainage of Peru. Swedish Museum Nat History 1986;1986:1-431.

60. Regan CT. A revision of the fishes of the South-American cichlid genera Acara, Nannacara, Acaropsis, and Astronotus. Annals Magazine Nat History 1905;15:329-347.

61. Ocalewicz K. Telomeres in fishes. Cytogenet Genome Res 2013;141:114-125.

62. Schneider CH, Gross MC, Terencio ML, Artoni RF, Vicari MR, Martins C, et al. Chromosomal evolution of neotropical cichlids: the role of repetitive DNA sequences in the organization and structure of karyotype. Rev Fish Biol Fish 2013; 23:201-214.

63. Slijepcevic P. Telomeres and mechanisms of Robertsonian fusion. Chromosoma 1998;107:136-140.

64. Ocalewicz K. Genomic distribution of telomeric DNA sequences-what do we learn from fish about telomere evolution? In: Reviews on Selected Topics of Telomere Biology. Li B (ed), pp. 271-294, Intech Open Access Publisher, 2012.

65. Mandrioli M, Bizzaro D, Manicardi GC, Gionghi D, Bassoli L, Bianchi U. Cytogenetic and molecular characterization of a highly repeated DNA sequence in the peach potato aphid Myzus persicae. Chromosoma 1999;108:436-442.

66. Devlin RH, Nagahama Y. Sex determination and sex differentiation in fish: an overview of genetic, physiological, and environmental influences. Aquaculture 2002;208:191364.

67. Cioffi MB, Martins C, Vicari MR, Rebordinos L, Bertollo LAC. Differentiation of the XY sex chromosomes in the fish Hoplias malabaricus (Characiformes, Erythrinidae): unusual accumulation of repetitive sequences on the $\mathrm{X}$ chromosome. Sex Dev 2010;4:176-185.

68. Ezaz T, Deakin JE. Repetitive sequence and sex chromosome evolution in vertebrates. Adv Evol Biol 2014; 2014:9.

69. Cioffi MB, Yano CF, Sember A, Bertollo LAC. Chromosomal evolution in lower vertebrates: sex chromosomes in Neotropical fishes. Genes 2017;8:pii: E258.

70. Sochorová J, Garcia S, Gálvez F, Symonová R, Kovařík A. Evolutionary trends in animal ribosomal DNA loci: intro- duction to a new online database. Chromosoma 2018;127: 141-150.

71. Guillén AKZ, Hirai Y, Tanoue T, Hirai H. Transcriptional repression mechanisms of nucleolus organizer regions (NORs) in humans and chimpanzees. Chromosome Res 2004; 12:225-237.

72. Nirchio M, Oliveira C, Ferreira IA, Granado A, Ron E. Extensive polymorphism and chromosomal characteristics of ribosomal DNA in the characid fish Triportheus venezuelensis (Characiformes, Characidae). Genet Mol Biol 2007;30:25-30.

73. Oliveira IA, Argolo LA, Bitencourt J de A, Diniz D, Vicari MR, Affonso PRA de M. Cryptic chromosomal diversity in the complex "Geophagus" brasiliensis (Perciformes, Cichlidae). Zebrafish 2016;13:33-44.

74. Cabrero J, Camacho JPM. Location and expression of ribosomal RNA genes in grasshoppers: abundance of silent and cryptic loci. Chromosome Res 2008;16:595-607.

75. Vicari MR, Artoni RF, Moreira-Filho O, Bertollo LAC. Colocalization of repetitive DNAs and silencing of major rRNA genes. A case report of the fish Astyanax janeiroensis. Cytogenet Genome Res 2008;122:67-72.

76. Ruiz-Estévez M, Ruiz-Ruano FJ, Cabrero J, Bakkali M, Perfectti F, López-León MD, et al. Non-random expression of ribosomal DNA units in a grasshopper showing high intragenomic variation for the ITS2 region. Insect Mol Biol 2015;24:319-330.

77. Mani I, Kumar R, Singh M, Nagpure NS, Kushwaha B, Srivastava PK, et al. Nucleotide variation and physical mapping of ribosomal genes using FISH in genus Tor (Pisces, Cyprinidae). Mol Biol Rep 2011;38:2637-2647.

78. Horigome C, Unozawa E, Ooki T, Kobayashi T. Ribosomal RNA gene repeats associate with the nuclear pore complex for maintenance after DNA damage. PLoS Genet 2019;15: e1008103.

79. Salim D, Gerton JL. Ribosomal DNA instability and genome adaptability. Chromosome Res 2019;27:73-87.

80. Amemiya CT, Gold JR. Chromosomal NORs as taxonomic and systematic characters in North American cyprinid fishes. Genetica 1988;76:81-90.

81. Majtánová Z, Symonová R, Arias-Rodriguez L, Sallan L, Ráb P. "Holostei versus Halecostomi" problem: insight from cytogenetics of ancient non teleost Actinopterygian fish, bowfin Amia calva. J Exp Zool B Mol Dev Evol 2017; 328:620-628.

82. Gornung E. Twenty years of physical mapping of major ribosomal RNA genes across the teleosts: a review of research. Cytogenet Genome Res 2013;141:90-102.

83. Kullander SO. A revision of the South American cichlid genus Cichlasoma (Teleostei: Cichlidae). Naturhistoriska Riksmuseet, Stockholm 1983;I-IV:1-296.

84. Argôlo LA, Affonso PRA de M. First cytogenetic report in Cichlasoma sanctifranciscense Kullander, 1983 (Perciformes, Cichlidae) from northeastern Brazil with inferences on chromosomal evolution of Cichlasomatini. Comp Cytogenet 2015;9:671-681.

85. Quoy JRC, Gaimard JP. Description des Poissons. Chapter IX. In: Voyage autour du Monde, Entrepris par Odre du Roi, exécuté sur les corvettes de L. M. "L'Uranie" et "La Physicienne," pendant les années 1817, 1818, 1819 et 1820. Freycinet L de (ed), pp. 192-401. Paris, 1824.

86. Gosse JP. Description de deux Cichlides nouveaux de la région Amazonienne. Bulletin Institut Royal Sciences Naturelles Belgique 1963;39:1-7. 
87. Martins C, Wasko AP. Organization and evolution of 5S ribosomal DNA in the fish genome. Focus Genome Res 2004;289:318.

88. Rebordinos L, Cross I, Merlo A. High evolutionary dynamism in 5S rDNA of fish: state of the art. Cytogenet Genome Res 2013;141:103-113.

89. Vicari MR, Ferreira Artoni R, Moreira-Filho O, Bertollo LAC. Basic and molecular cytogenetics in freshwater Cichlidae (Osteichthyes, Perciformes). Karyotypic conservationism and divergence. Caryologia 2006;59:260-266.

90. García-Souto D, Troncoso T, Pérez M, Pasantes JJ. Molecular cytogenetic analysis of the European hake Merluccius merluccius (Merlucciidae, Gadiformes): U1 and U2 snRNA gene clusters map to the same location. PLoS One 2015;10:e0146150.
91. Cabral-de-Mello DC, Valente GT, Nakajima RT, Martins C. Genomic organization and comparative chromosome mapping of the U1 snRNA gene in cichlid fish, with an emphasis in Oreochromis niloticus. Chromosome Res 2012;20:279-292.

Address correspondence to: Anna Rita Rossi, PhD

Dipartimento di Biologia e Biotecnologie "C. Darwin" Sapienza-Università di Roma Via Alfonso Borelli 50 Rome 00161 Italy

E-mail: annarita.rossi@uniroma1.it 